\section{EFFICIENCY DENENARDE}

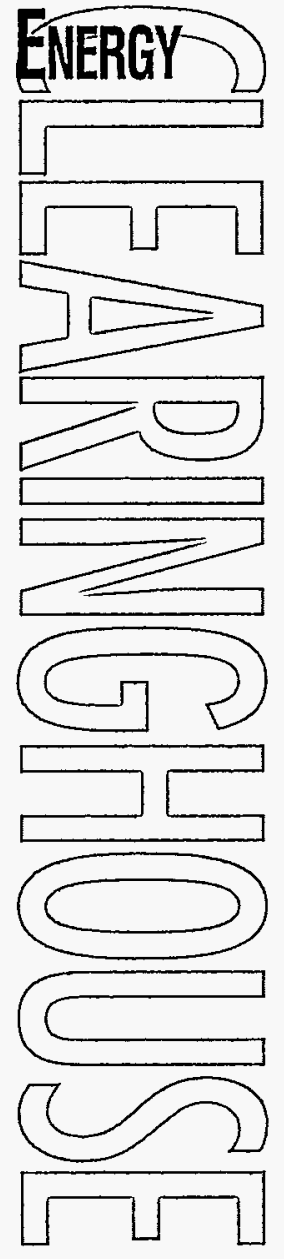

\title{
Loose-Fill Insulations
}

Whether you are increasing the insulation levels in your current home or selecting insulation for a new home, choosing the right insulation material can be challenging. Fibrous loose-fill insulations such as cellulose, fiberglass, and rock wool are options you may wish to consider. This publication will introduce you to these materials-what they are, how they are applied, how they compare with each other, and other considerations regarding their use-so that you can decide whether loose fills are right for your home.

\section{Character and Types of Loose-Fill Insulation}

The most obvious difference between loose fills and other types of insulation is their form. They are either produced as-or broken down into-shreds, granules, or nodules. These small particles form fluffy materials that conform to the spaces in which they are installed. Loose fills are most commonly sold in bags and are blown into building cavities using special equipment. All three primary types of loose-fill insulation are considered "environmentally positive" because recycled waste materials are used in their production.

Cellulose loose-fill insulation is made from wastepaper, such as used newsprint and boxes, that is shredded and pulverized into small, fibrous particles. Chemicals are added to provide resistance to fire and insects. Also, less energy is required to produce loose-fill cellulose than to produce other insulations.

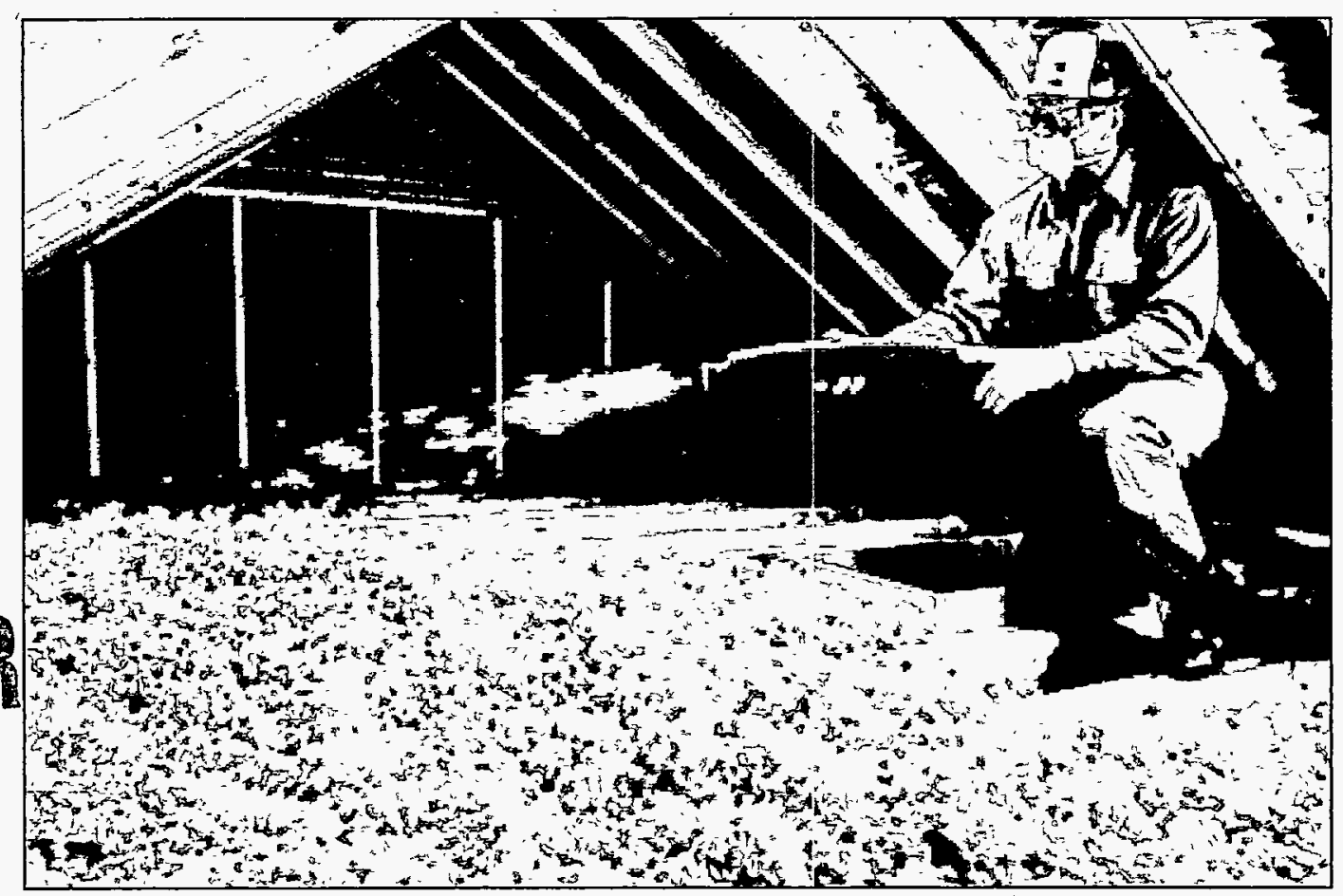

Loose-fill insulation is typically.installed with special equipment that forces it through a hose at the proper density.

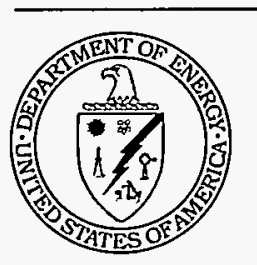

This document was produced for the U.S. Department of Energy (DOE) by the National Renewable Energy Laboratory (NREL), a DOE national laboratory. The document was produced by the Technical Information Program, under the DOE Office of Energy Efficiency and Renewable Energy. The Energy Efficiency and Renewable Energy Clearinglouse (EREC) is operated by NCI Information Systems, Inc., for NREL / DOE. The statements contained herein are based on information known to EREC and NREL at the time of printing. No recommendation or endorsement of any product or service is implied if mentioned by EREC. 


\section{Loose-fill insulations}

are well suited for

places where it

is difficult to install

other types of

insulation.
Fiberglass loose-fill insulation is spun from molten glass into fibers. The glass is typically melted in high-temperature gas furnaces. Most major manufacturers use $20 \%$ to $30 \%$ recycled glass content.

Rock wool (or slag wool) loose-fill insulation is similar to fiberglass except that it is spun from blast furnace slag (the scum that forms on the surface of molten metal) and other rock-like materials instead of molten glass. The production of rock wool uses byproducts that would otherwise be wasted.

\section{Primary Applications of Loose-Fill Insulations}

Loose-fill insulations are well suited for places where it is difficult to install other types of insulation, such as irregularly shaped areas, around obstructions (such as plumbing stacks), and in hard-to-reach places. They can be installed in either enclosed cavities such as walls or unenclosed spaces such as attics. Blown-in loose fills are particularly useful for retrofit situations because, except för the holes that are sometimes drilled for installations, they are one of the few materials that can be installed without greatly disturbing existing finishes. Rock wool or slag wool loose-fill insulation is often used for insulating existing walls and ceilings in mobile homes.

In most new construction, however, the more common choices in insulation are batts or rolls because they can be installed

\begin{tabular}{|c|c|c|c|}
\hline \multicolumn{4}{|c|}{ Recommended Specifications by Insulation Type } \\
\hline & Cellulose & Fiberglass & Rock Wool \\
\hline R-value/inch & $3.2-3.8$ & $2.2-2.7$ & $3.0-3.3$ \\
\hline $\begin{array}{l}\text { Inches }(\mathrm{cm}) \text { needed } \\
\text { for } \mathrm{R}-38\end{array}$ & $10-12(25-30)$ & $14-17(35-43)$ & $11.5-13(29-33)$ \\
\hline $\begin{array}{l}\text { Density in } \mathrm{lb} / \mathrm{ft}^{3} \\
\left(\mathrm{~kg} / \mathrm{m}^{3}\right)\end{array}$ & $1.5-2.0(24-36)$ & $0.5-1.0(10-14)$ & $1.7(27)$ \\
\hline $\begin{array}{l}\text { Weight at R-38 in } \\
\mathrm{lb} / \mathrm{ft}^{2}\left(\mathrm{~kg} / \mathrm{m}^{2}\right)\end{array}$ & $1.25-2.0(6-10)$ & $0.5-1.2(3-6)$ & $1.6-1.8(8-9)$ \\
\hline $\begin{array}{l}\text { OK for } 1 / 2 \text { " drywall, } \\
24^{\prime \prime} \text { on center? }\end{array}$ & No & Yes & No \\
\hline $\begin{array}{l}\text { OK for } 1 / 2^{\prime \prime} \text { drywall, } \\
16^{\prime \prime} \text { on center? }\end{array}$ & Yes & Yes & Yes \\
\hline $\begin{array}{l}\text { OK for } 5 / 8^{\prime \prime} \text { drywall, } \\
24^{\prime \prime} \text { on center? }\end{array}$ & Yes & Yes & Yes. \\
\hline
\end{tabular}

without the use of special equipment before walls are finished. Batts are available in standard widths designed to match the cavities created by wall studs.

Loose fills are sometimes used in new construction, though. A mixture of loose-fill insulation and an adhesive can be sprayed into wall cavities before the walls are closed. Such methods may result in fewer gaps in the building's thermal envelope than can occur with batts.

\section{Comparative Performance of Loose-Fill Insulations}

Insulation materials are compared on the basis of their R-values per unit of thickness, density per unit of volume, ${ }_{r}$ and weight per unit of area.

There are several performance characteristics to consider when selecting an insulation material. Among the most important to compare are insulating capacity, weight, convective heat loss, settling and loss of insulating capacity, fire resistance, and moisture resistance.

\section{Insulating Capacity}

A material's resistance to heat flow is expressed as its $\mathrm{R}$-value. The higher the $\mathrm{R}$-value, the better the material insulates, and the lesser the thickness you will need. (However, in an open, unrestricted attic application, the height limit of insulation thickness is of no great concern. But if you use your attic for storage, heavy objects will compress insulation and decrease its benefits.) Different insulations also have different densities, or weights. There are weight limits for certain ceiling types (see the chart and the section on Weight that follows).

Weight limits and other factors at R-38 insulation levels are shown in the chart on this page for the three primary types of loose fills. (R-38 is a commonly recommended ceiling insulation level in many parts of the United States. To determine the recommended insulation levels for your area, call the Energy Efficiency and Renewable Energy Clearinghouse (EREC) listed in the Source List to request the U.S. Department of Energy's Insulation Fact Sheet.) 


\section{DISCLAIMER}

This report was prepared as an account of work sponsored by an agency of the United States Government. Neither the United States Government nor any agency thereof, nor any of their employees, make any warranty, express or implied, or assumes any legal liability or responsibility for the accuracy, completeness, or usefulness of any information, apparatus, product, or process disclosed, or represents that its use would not infringe privately owned rights. Reference herein to any specific commercial product, process, or service by trade name, trademark, manufacturer, or otherwise does not necessarily constitute or imply its endorsement, recommendation, or favoring by the United States Government or any agency thereof. The views and opinions of authors expressed herein do not necessarily state or reflect those of the United States Government or any agency thereof. 


\section{DISCLAIMER}

Portions of this document may be illegible in electronic image products. Images are produced from the best available original document. 


\section{A tight, well-sealed}

home is more energy

efficient and needs

less insulation to keep

you and your family

comfortable.

\section{Weight}

Ceiling drywall can sag under heavy loads, such as those sometimes created by insulation. One drywall manufacturer recommends loads of no more than 1.3 pounds '. per square foot (6 kilograms per square meter) for $1 / 2$-inch (1.3-centimeter) ceiling drywall with framing spaced 24 inches (61 centimeters) on center. The limit increases to 2.2 pounds per square foot (11 kilograms per square meter) for framing spaced 16 inches (41 centimeters) on center and for-5/8-inch (1.6-centimeter) drywall.

Loose-fill cellulose and rock wool, being heavier materials, could cause the ceiling to sag if installed at R-38 on 1/2-inch (1.3-centimeter) ceiling drywall with framing spaced 24 inches (61 centimeters) on center (see chart). Therefore, when deciding whether to use these materials for new construction, consider switching to 5/8-inch ceiling drywall or, if possible, changing your ceiling framing widths to 16 inches on center.

Some cellulose and rock wool insulation. manufacturers include weight limit information on the bag. Because fiberglass is much less dense, its weight on ceiling drywall is not a concern.

\section{Convective Heat Loss}

Convection is heat flow caused by air currents. Convective heat loss in insulation is rare, but it can occur when large temperature differences above and below insulation create tiny air currents (called "convection loops") within the insulation. Studies have shown that convective heat loss can occur with lighter density loose-fill fiberglass at the very low attic temperatures possible in extremely cold climates. Depending on the attic temperature, the insulation's measured R-value could decrease by as much as $50 \%$.

To minimize these convection loops and their associated effects, some researchers : suggest installing blown-in cellulose or a fiberglass blanket on top of the loose-fill fiberglass: Another solution is to purchase one of the currently available "convection blanket". products that can inhibit this convective heat loss.

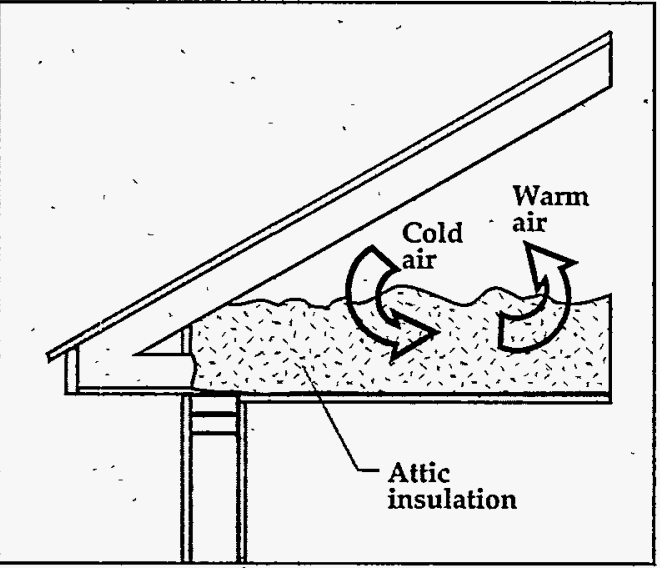

Convective heat loss in loose-fill insulation occurs as dense, cold air drops and lighter, warm air rises. However, this only occurs in homes in very cold climates.

Cellulose and rock wool are more resistant to airflow than fiberglass because they are denser. They may also be more effective at reducing air leakage and associated heat loss, because their higher densities cause them to settle and seal more around rafters and in corners.

Sprayed-in-place foam insulations are an alternative to-loose fills in some applications.: They offer higher R-values at lower thicknesses than loose fills and, when properly installed, can help stop air leakage.

But no insulation, by itself, provides an effective air retarder because it cannot completely block airflow. Installing an air retarder along with your insulation and using caulking and weatherstripping seals all gaps and greatly reduces air infiltration into your home (see the section on Air. Retarders that follows).

\section{Settling and Loss of Insulating Capacity}

Many loose-fill insulations installed in attic cavities will lose some of their installed R-value over time because of settling. Cellulose loose fill settles more than rock wool or fiberglass loose fill-about $20 \%$ compared to roughly $2 \%$ to $4 \%$. Therefore, install about $20 \%$ more blownin cellulose insulation to offset this settling. Cellulose manufacturers are 


\section{Loose-fill insulations}

are especially popular.

for retrofit projects.

An air retarder is

different from a vapor

retarder in that it

blocks only air, not

moisture. required by federal law to state "settled thickness" on their bags. Because this can be confusing to consumers, many cellulose producers also specify "installed thickness" on their bags. Regardless, installed thickness can be estimated by adding $20 \%$ to the stated settled thickness, but be sure not to exceed previously mentioned weight limits.

Researchers say that it is possible to install loose-fill insulations in wall cavities without settling. If the cavity is completely filled with insulation at the proper density, no significant settling should occur. A general density guideline for walls is roughly 3.5 pounds per cubic foot (17 kilograms per cubic meter) of wall cavity for cellulose and 1.5 pounds per cubic foot (7 kilograms per cubic meter) for fiberglass or rock wool. These specifications are roughly twice the density of horizontal applications.

One expert suggests this easy-to-follow guideline to ensure that wall cavities are being filled at a density sufficient to prevent settling. Use roughly one 30-pound (13-kilogram) bag of cellulose or about 15 pounds ( 8 kilograms) of fiberglass or rock wool for every three wall cavities you fill. (Assumptions: 8-foot [2.4-meter] walls, with 16-inch [41-centimeter] on center wall cavities, and $2 \times 4$-inch framing studs.)

\section{Fire Resistance}

Loose-fill insulations offer very good resistance to fire. Although fiberglass and rock wool are naturally fire resistant, cellulose's fire resistance is achieved by adding chemicals. To ensure that it does not present a fire hazard, cellulose must pass tests established by the Consumer Product Safety Commission.

\section{Moisture Resistance}

The average household generates a considerable amount of water vapor each day through activities such as cooking, laundry, and bathing. This vapor migrates into insulated cavities and, if it reaches the dew point (the air temperature at which water vapor cools enough to condense), it converts to liquid within the insulation. This reduces the insulation's effective R-value.
All loose-fill insulations are permeable to water vapor. Permeability is the extent to which water vapor can pass through a given material. Fiberglass and rock wool absorb about $1 \%$ of their weight, and cellulose absorbs $5 \%$ to $20 \%$ of its weight. However, any insulation can absorb large amounts of water if exposed to extremely high humidity.

Higher levels of outdoor moisture can also penetrate into insulated cavities. If your roof leaks, for example, moisture can accumulate in the attic cavity and wet the insulation to the point that it mats and compacts. Enough moisture penetration could even cause the ceiling to sag.

If insulation is saturated only one time, it will eventually dry and regain most of its original R-value. However, loose-fill insulations that are repeatedly saturated will lose much of their R-value. Moisture also causes additional problems, such as mold and mildew growth.

See the Vapor Retarders section that follows for steps you can take to ensure that moisture does not create a problem in your insulation.

\section{Before You Install Insulation}

\section{Upgrading or Repairing Other Building Components}

There are other home weatherizing and sealing measures to complete before you undertake any insulation project. A tight, well-sealed home is more energy efficient and needs less insulation to keep you and your family comfortable. Tests have shown that far more cold air infiltration and heat loss result from improperly sealed windows, doors, ducts, light switches, and outlets than from insufficient insulation coverage or performance. 


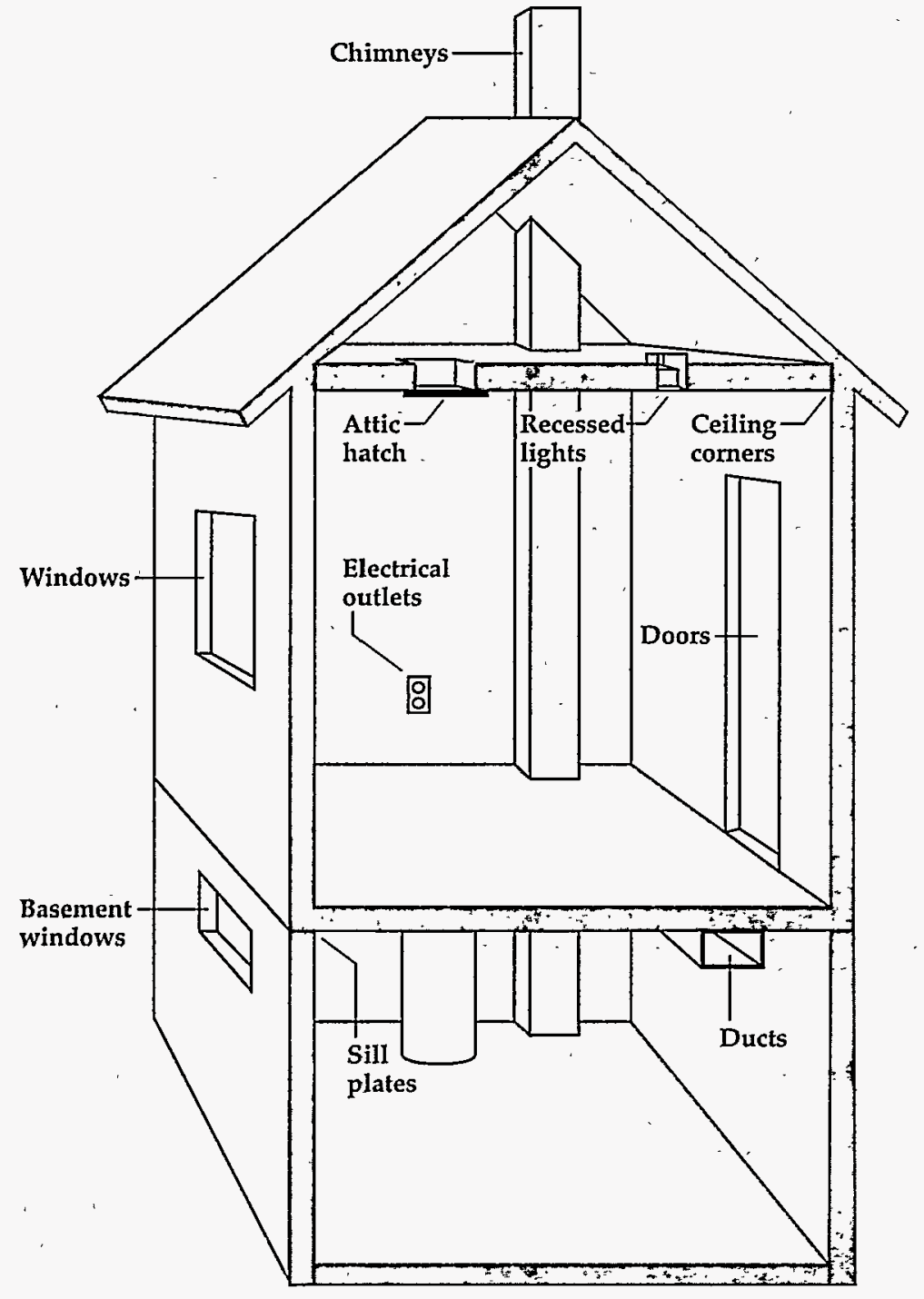

These common air leakage points should be properly sealed with caulk, weatherstripping, and insulation.
When installing loose-fill insulations, a material such as 6-mil (0.006-inch, or 0.015 -centimeter) polyethylene plastic sheeting can be used as a vapor retarder. Paints that act as vapor retarders are also available. These paints may be more practical for retrofitting homes where no vapor retarder exists because they can be installed without removing finished surfaces.

Federal Housing Administration Minimum Property Standards require that any product, including paint, must have a permeability (perm) rating of 1.0 or lower to qualify as a vapor retarder. The lower the perm rating, the greater the material's resistance to vapor penetration. For example, 15-pound (6.8-kilogram) asphalt felt paper has a perm rating of 1.0, while 6-mil polyethylene sheeting is rated at 0.06 , and common household aluminum foil is rated at 0.0001 .

If the drywall on your ceiling or wall is removed and the insulated area is completely exposed, you can install 6-mil polyethylene sheeting. Be sure that it runs continuously along the surface area of the ceiling and walls, and that no tears occur during installation. Additionally, all penetrations, such as electrical outlets and light switches, should be carefully sealed.' There are preformed foam gaskets for use behind outlets and switchplates.

\section{Air Retarders}

An air retarder reduces energy loss because it prevents heated or air-conditioned indoor air from escaping through the building shell. It also blocks drafts of hot or cold outside air-caused by winds and pressure differences between the inside and outside of the house- that reduce your home's comfort and heating or cooling efficiency.

An air retarder is different from a vapor retarder in that it blocks only air, not moisture. The American Society for Testing and Materials specifies that a material must have a perm rating of 5.0 or higher to qualify as an air retarder. Remember, the 
In a vapor barrier,

the lower the "perm

rating," the greater

the material's

resistance to vapor

penetration. higher the perm rating of a material, the more moisture can pass through it. An air retarder should have a high perm rating because this allows the escape of moisture that may have migrated into insulated cavities. In new construction, an air retarder (such as "housewrap" products that are now available) is often wrapped around the outside walls before installing the exterior finish, and a vapor retarder is installed around the inside walls before the interior finish is completed.

\section{Installation}

Loose-fill insulations are typically installed with special equipment that blows the insulation through a hose and into the cavity. Although loose fills can be installed in both new and retrofit situations, they are especially popular for retrofit projects because they can be installed with minimal disturbances to existing finishes.

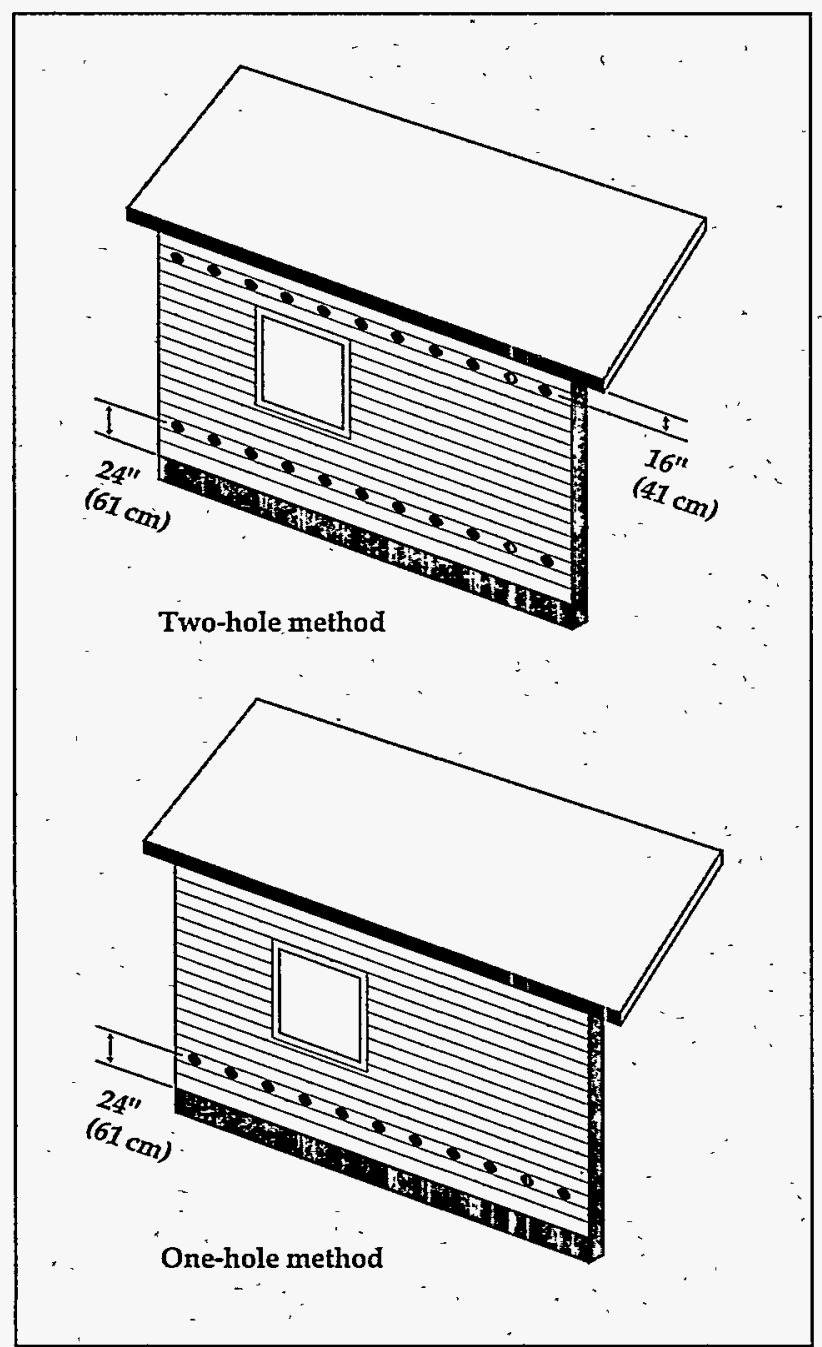

Holes used to install loose-fill insulation in walls must be properly positioned.
In conventional and cathedral ceilings, insulation is easier to blow in if an access opening through the ceiling already exists. Otherwise, it may be necessary to drill holes in the ceiling or between the roof rafters.

\section{Cost}

At the time this publication was written, the average loose-fill insulation cost per $R$-value per square foot was about 0.8 cents for cellulose and rock wool and 1.1 cents for fiberglass. These prices were for materials only. The average installed price per R-value per square foot was about 1.2 cents for blown-in cellulose and rock wool and 1.3 cents for fiberglass. Because prices vary in different regions, obtain bids from several insulation contractors or suppliers to determine the specific cost in your area.

\section{Installation Quality Control}

\section{Voids and Gaps}

To ensure a quality installation, there are several things to watch out for when installing loose-fill insulation-whether you do the job yourself or hire a professional.

You may create undesirable voids or gaps if you install the insulation at too low a density or if you do not completely fill the cavity. Voids are most likely to occur at the top of wall cavities, above windows, around doorways, and in the corners of ceiling cavities. Voids also occur if the installation holes are improperly located between the vertical framing studs or if there are too few fill holes. Keep in mind, though, that installers' practices may vary regarding the number, location, and size of installation holes.

It may be difficult to achieve recommended R-values with loose-fill insulation in the eave area of the attic. There are insulation techniques that can be used to insulate this area adequately. Contact the Energy Efficiency and Renewable Energy Clearinghouse (EREC-see Source List) for advice on this topic.

\section{Fluffing}

"Fluffing" occurs when insulation is installed to minimum thickness but not to minimum weight requirements. The result 
Low-density insulation

("fluffed")

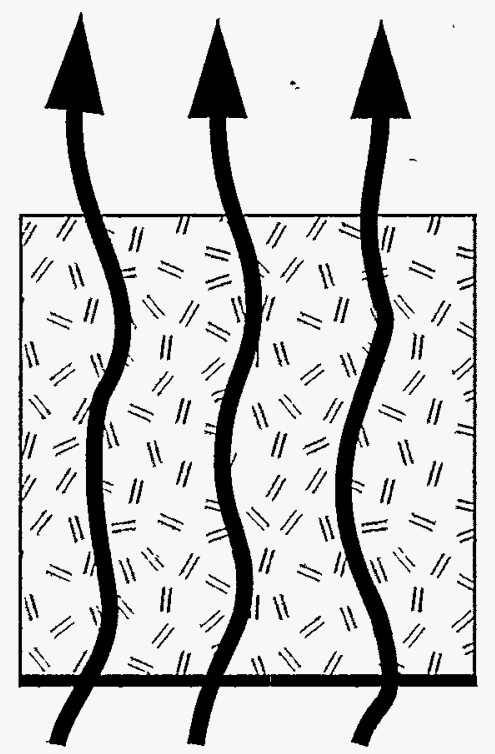

Air movement.
High-density insulation ("nonfluffed")

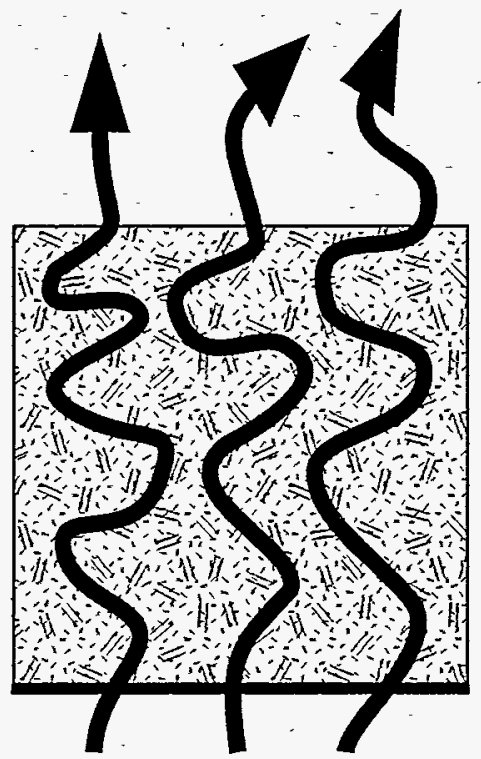

Air movement

When insulation is "fluffed" or blown in at too low a density, air moves more easily through it. This can result in increased heat loss.

\section{You may create}

\section{undesirable voids or}

\section{gaps if you install}

\section{the insulation at too}

low a density or if

you do not completely

fill the cavity. is a less dense application of insulation. that requires fewer bags. When insulation is "fluffed," air passes more easily through it. This means increased heat loss. Additionally, the fluffed loose-fill insulationwill eventually settle and result in a thinner layer with a lower overall $R$-value. Fiberglass is more "fluffable" than cellulose or rock wool.

Intentional fluffing by unscrupulous contractors has been a problem in some parts of the country. To avoid these problems, compare bids from several contractors to see how many bags they specify. Count. the number of bags used during installation, either by you or a contractor, and compare it to the instructions on the bag. The manufacturer should specify the amount of insulation required to obtain a particular R-value per square foot (or square meter) of space.

\section{Safety and Health Concerns}

\section{Safety Guidelines}

Insulation blown into your ceiling cavities should cover the top plate of the wall, but be sure the eave vents are not covered. These vents provide necessary ventilation to your attic, and covering them could result in severe moisture problems.

Electrical devices and recessed lights (except "IC-rated" fixtures) require 3 inches (8 centimeters) of clearance from insulation.

Pipes for kitchen stoves, wood stoves, and furnaces should only be insulated with fiberglass or rock wool because cellulose may smolder if flue temperatures become hot enough.

\section{Health Considerations}

Some observers contend that fiberglass particles can cause cancer if inhaled, and others state that the fire retardants and insecticides added to cellulose may be harmful to breathe. While the debate continues as to the health effects of loose-fill insulations, it is important to protect yourself when installing any type of insulation. Wear a quality respirator, and wear protective eyewear and clothing such as goggles, gloves, long-sleeved shirts, and pants to minimize contact with the insulation.

Insulation fibers can also be drawn into air distribution systems if the ducts are not properly sealed, allowing the fibers to circulate within the living space. Be sure to seal all of your home's ductwork, as well as any other openings. where insulation could leak out of the wall or ceiling cavities and into your living space.

\section{Conclusion}

Cellulose, fiberglass, and rock wool loosefill insulations are good choices for many insulation projects. However, they are not suitable for all situations. Conduct careful research and consider factors such as your climate, building design, and budget when selecting the best insulation for your specific circumstances. If you control air leakage and ensure that the insulation you select is installed properly, you can reduce your energy bills and enjoy a more comfortable home. For information on insulation installation techniques and on other ways to weatherize, to select materials, and to make your home more energy efficient, contact EREC (see Source List). 


\section{Source List}

There are many groups that can provide you with more information on loose-fill insulation strategies. The following are just a few of the organizations that can assist you.

\section{Cellulose Insulation Manufacturers Association (CIMA)}

136 South Keowee Street

Dayton, $\mathrm{OH} 45402$

(513) 222-2462

CIMA is a trade association for manufacturers of cellulose insulation and is a source of information on cellulose and other types of insulation.

Insulation Contractors Association of America (ICAA) 1321 Duke Street, Suite 303

Alexandria, VA 22314

(703) 739-0356

ICAA is a consumer-oriented association that provides information on insulation issues to homeowners and other consumers.

\section{North American Insulation Manufacturers Association} (NAIMA)

44 Canal Center Plaza, Suite 310

Alexandria, VA 22314

(703) 684-0084

Fax: (703) 684-0427

NAIMA is a trade association for manufacturers of fiberglass, rock wool, and slag wool insulation products. NAIMA's role is to promote energy efficiency and environmental preservation through the use of these products and to encourage safe production and use of insulation materials.

For general information about many kinds of energy efficiency and home weatherization topics, contact:

\section{The Energy Efficiency and Renewable Energy \\ Clearinghouse (EREC)}

P.O. Box 3048

Merrifield, VA 22116

(800) DOE-EREC (363-3732)

Fax: (703) 893-0400

EREC provides free general and technical information to the public on the many topics and technologies pertaining to energy efficiency and renewable energy.

You may also contact your state and local government energy offices for region-specific information on insulation and energy efficiency.

\section{Reading List}

\section{Books and Journals}

The Complete Book of Insulating, L. Gay, ed., The Stephen Greene Press, 1980. (This book is out of print, so check to see if your local library has a copy.)

Energy Design Update, 235 West 102nd Street, \#7], New York, NY 10025, monthly publication.

Home Insulation: Do It Yourself E Save As Much As 40\%, H. Yost, Storey Communications, Inc., Schoolhouse Road, Pownal, VT 05261, 1991.

Residential Building Design \& Construction Workbook, second edition, J.D. Nisson, ed., Cutter Information Corporation, 37 Broadway, Arlington, MA 02174, 1988.

Thermal Insulation Building Guide, E. Strother and W. Turner, Krieger Publishing Company, Malabar, FL 32950, 1990.

\section{Articles}

"A Cozier and Cheaper Home: Home Energy's Guide to Insulation," C. Penn, Home Energy, pp. 30-34, January/February 1992.

"Air Sealing Details," Journal of Light Construction, p. 15, August 1993.

"Cellulose Fire Retardancy-Does Boric Acid Disappear Over Time?" Energy Design Update, pp. 4-5, June 1986.

"Cellulose Insulation: An In-Depth Look at the Pros and Cons," Environmental Building News, pp. 1, 12-17, September/October 1993.

"Good News About Low-Density Cellulose Attic Insulation," Energy Design Update, p. 5, April 1993.

"Is Fiberglass Insulation Safe?" P. DuPont, Home Energy, pp. 5-10, March/April 1988.

"Measured Performance of Loose-Fill Fiberglass Attic Insulation-The Oak Ridge Tests," Energy Design Update, pp. 6-8, August 1990.

" ' $R$ ' Wars-Cellulose and Fiberglass Duke It Out," T. Maker, Journal of Light Construction, p. 56, November 1993.

"Retrofit Wall Insulation: Is There Really Quality In That Corner?" Energy Auditor \& Retrofitter, pp. 6-10, September/October 1985. 